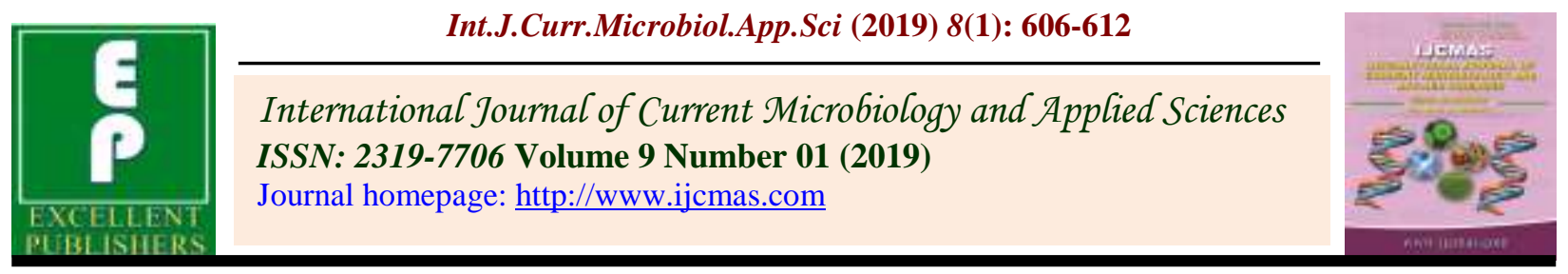

Original Research Article

https://doi.org/10.20546/ijcmas.2019.801.068

\title{
Predicting Draft Requirement of Tillage Implements Using Pull Type Load Cell in Southern Region of Andhra Pradesh, India
}

\author{
Bikram Jyoti $^{*}$, K.V.S. Ram Reddy ${ }^{2}$, Chetankumar P. Sawant ${ }^{1}$, A.P. Pandirwar ${ }^{1}$, \\ R.R. Potdar ${ }^{1}$ and R.D. Randhe ${ }^{1}$ \\ ${ }^{1}$ ICAR-Central Institute of Agricultural Engineering, Bhopal, 462038 India \\ ${ }^{2}$ Collage of Agricultural Engineering, ANGRAU, Bapatla, 522101 India
}

*Corresponding author

\section{A B S T R A C T}

Keywords

Tillage, Cone index, Bulk density, Draft

Article Info

Accepted:

07 December 2018

Available Online:

10 January 2019
Availability of draft requirement data of primary and secondary tillage implement is necessary to implement selection, tractor- implement matching and determination of fuel consumption for different tillage systems. In this research, pull type load cell was along with an auxiliary tractor was used to determine the draft requirement of selected tillage implement. It was observed that the draft requirement of $\mathrm{Mb}$ plough was maximum at 619 kgf compared to disc plough, disc harrow and cultivator. The draft effecting soil parameters were also determined. The average value moisture content, bulk density and cone index were found to $8.54 \%, 1.91 \mathrm{~g} / \mathrm{cc}$ and $1.45 \mathrm{MPa}$.

\section{Introduction}

The world is facing the problem of extreme climate change which has resulted in confrontation of food, water and energy. The existing problem of global population rise has stressed the researchers around the globe for optimum use of resources in agricultural production system to feed ever burgeoning population. Hence, a sustainable agricultural approach is required to increase the agricultural productivity against the backdrop of limited resources and climate change.

Tillage operation is one of the most important aspects of crop production system and its energy requirement represents the major portion of energy utilized for crop development (Suhaibani and Janobi, 1997). The availability of draft requirement data for tillage implements under different soil conditions is necessary for selection of suitable machinery, implement matching and prediction of fuel consumption during field operation (Suhaibani, 2010; Srivastava et al., 2006; Upadhyaya et al., 2009; Bowers and Crowell, 1985). The estimation of draft requirement data can be useful for minimal use of input resources in increasing the crop productivity by increasing input use efficiency (Larsonand Clyma, 1995; Grisso et al., 1996). 
Researchers around the globe had conducted various studies to predict the draft requirement of different tillage implements under different soil conditions. In general, the drafts of different tillage tools are measured by either dynamometers or three point hitch dynamometers (Finnerand Straub, 1985; Gill et al., 1967, Gill et al., 1968; Harrigan and. Rotz. 1994). Implement width, operating depth and speed are the major factors which effect the draft requirement of tillage tools.A previous study on prediction of draft requirement has ascertained that the effect of speed on draft is complimented by soil type and type of implement (Taniguchi et al., 1999; Zwilling and Hummel, 1988).The studies conducted and results obtained in various researches on draft prediction of tillage implement have been summarized in ASABEStandard D497.5. This standard uses a simplified draftprediction equation proposed by:

$\mathrm{D}=\mathrm{F}[\mathrm{A}+\mathrm{B} \times \mathrm{S}+\mathrm{C} \times \mathrm{S}] \mathrm{W} \mathrm{T}(1)$

Where

$\mathrm{D}=$ Draft force on implement

$\mathrm{F}=$ Soil texture adjustment parameter

A, B and C = Machine-specific parameters

$\mathrm{S}=$ Forward speed of vehicle

$\mathrm{W}=$ Implement width

$\mathrm{T}=$ Tillagedepth.

The above draft prediction equation is suitable for wide range of soil conditions up to $\pm 50 \%$ can be expected within the samebroad textural soil class (Mamman and Oni, 2005; Naderloo et al., 2009; Okoko, 2017; Olatunji et al., 2009).

Anantapur is located in southern district of Andhra Pradesh where most of the agricultural operations are done still done manually. The present scenario affirms a very favorable situation for mechanization in this southern district. There are many tillage systems where different combinations of primary and secondary tillage are used. To promote mechanization with more energy efficient system, it is necessary to have draft and energy data. Keeping the above problem in view, a study was undertaken to determine the draft requirement of primary and secondary tillage implement under present cropping system of anantapur district.

The present research also helps in establishing the relationship of draft between primary and secondary tillage implements, which will help in modeling the tillage practices to reduce fuel consumption and net cost. The study will also affirm the applicability of draft predication equations suggested by various researchers.

\section{Materials and Methods}

In India, land preparation is mainly done by primary and secondary tillage implements. To promote mechanization in country it is important to use tractor drawn implements. In order to increase the input use efficiency of these land preparation implement determination of draft is an essential aspect. In this regard, two primary and two secondary tillage implements were selected for this study. The details of test plot and each implement are explained in details below.

\section{Experimental site}

The test was conducted at situated at southern region farm machinery training and testing institute Garladinne, Anantapur (AP) at latitude of $14.83^{\circ} \mathrm{N}$ and longitude of $77.61^{\circ} \mathrm{E}$ at an altitude of $342 \mathrm{~m}$ from sea level The site was about $24 \mathrm{kms}$ away from Anantapur District place and $4 \mathrm{kms}$ from Geraldine town. The topography of the field site was flat $(<1 \%)$ and the red sandy clays loam with properly drained and aerated. The average organic content was $74 \%$ of weight with average $\mathrm{pH}$ was 8.5 . 


\section{Characterization of soil properties for measurement of draft}

The soil property which mainly affects the draft and energy requirement of primary and secondary tillage implements are mainly; soil moisture content, bulk density, cone index and soil texture. Soil moisture content of the soil samples were determined by the hot air oven method. The soil samples were randomly selected from 10 different places of each test plot. Soil samples were weighed, oven dried at $105^{\circ} \mathrm{C}$ for $24 \mathrm{~h}$ and again weighed. The moisture content of the test samples were calculated on dry basis. Bulk density of the soil samples were determined by tube core method. The core sampler was driven into the soil and soil collected was weighed followed by estimation of core sampler volume. The ratio of weight on volume gave the bulk density of the sample. Cone Index was measured at 30 places in the test plot over $0-30 \mathrm{~cm}$ depth immediately before tillage operation using cone penetrometer. The cone index of the samples were below $1.5 \mathrm{MPa}$ indicating the suitability of soil for agricultural cultivation.

\section{Implements selected for draft measurement}

The tillage operation in India is mainly done by primary and secondary tillage implements. Two primary tillage implement i.e. moldboard plough, disc plough and two secondary tillage implement i.e. disc harrows, and cultivators were selected for the study. Since the draft requirement data is useful for selection of suitable machinery and proper.

\section{Mb plough}

A two bottom moldboard plough mounted on one tool bar was selected for measurement of draft requirement. The soil engaging tools were spaced $380 \mathrm{~mm}$ apart making the size of plough as $760 \mathrm{~mm}$. The plough had bar point share with general purpose moldboard and was set to operate at $35 \mathrm{~cm}$.

\section{Disc plough}

The disc plough consisted of 2 bottom with disc diameter of $660 \mathrm{~mm}$. The $260 \mathrm{~kg}$ disc was had provision to add ballast weight to the implement. The disc plough was set to operate at an average depth of $21-23 \mathrm{~cm}$.

Disc harrow: To measure the draft of the secondary tillage implement disc harrow was selected. The two gang disc harrow comprised of 12 discs (6 discs in each gang) spaced 228 $\mathrm{mm}$ apart. The gang axle of was made square bar to mount each gang on which disc was mounted. The disc harrow was suitable for light and medium textured soil. The disk plough was set to operate at $12-15 \mathrm{~cm}$.

\section{Cultivator}

A nine tyne four on front row and five on second row rigid tyne cultivator was selected for the field test. The working width of the cultivator was $1750 \mathrm{~mm}$ with reversible shovel attached to each shank. The cultivator was set to operate at $8-10 \mathrm{~cm}$.

\section{Experimental field procedure}

The field experiment was conducted in a test field of $100 \mathrm{~m} \times 50 \mathrm{~m}$ in accordance withthe norms of the Regional network for Agricultural machinery (RNAM, 1983). The performance parameters i.e. Soil inversions, soil aggregation, and depth of cut and width of cut, fuel consumption were recorded at three different forward speeds. Two tractors namely John deer/5310E (Table 1) and Mahindra /575 DI (Table 2) were used to calculate the draft of the tillage tool.

The implements under study were mounted at the rear of Mahindra /575 DI with help of three point hitch of the tractor. A hydraulic dynamometer (pull type) was attached to the front of Mahindra /575 DItractor. 
An auxiliary tractor John deer/5310E was used to pull the implement mounted through dynamometer. The auxiliary tractor pulled the implement mounted tractor in neutral gear with implement in operating condition. The idle draft force was also recorded in the same field when implement was in lifted position. The difference draft at operating and idle condition gave the draft required to pull the implement. The operation was repeated for five consecutive runs and draft data for each run was recorded.

The depth of cut and width of cut for each selected implement was measured from bottom of the furrow to the surface level of the soil at 10 randomly selected places for each run in the test plot.

\section{Results and Discussion}

The draft requirement of primary and secondary tillage implements were determined using pull type load cell. The soil parameters which effect the draft requirement of the implements such as moisture content, bulk density and cone index were determined. The results showed that the average moisture content of selected soil samples from the test plot varied between $8.5-8.9 \%$ on dry basis. Bulk density of the soil samples varied between 1.81-1.91 $\mathrm{g} / \mathrm{cc}$ whereas the cone index varied from $1.2 \mathrm{MPa}-1.5 \mathrm{MPa}$ at different depth. The observed results led to conclude that mold board plough require more draft at same speed and same soil condition compared to disc plough, disc harrow and cultivator. The draft of mb plough was observed to be $619.2 \mathrm{kgf}$ at average moisture content of $8.54 \%$ and average bulk density of $19.1 \mathrm{~g} / \mathrm{cc}$. The draft obtained for different selected primary and secondary tillage implement are illustrated in table 3 . The draft of each implement increased with increase in depth of cut and forward speed (Fig. 1).

Table.1 Specification of test tractor I

\begin{tabular}{|l|l|}
\hline Specifications & Value \\
\hline Type/Model & John deer/5310E \\
\hline Effective output (hp) & 55 \\
\hline Type of Engine & 3 Cylinder \\
\hline Type of steering system & Power steering with tilt able steering column \\
\hline Type of injector pump & In line fuel injection pump \\
\hline Fuel tank capacity (L) & 68 \\
\hline Lifting capacity (kgf) & 2000 \\
\hline Rated engine speed (rpm) & 2400 \\
\hline Type of cooling system & Water cooled \\
\hline Front tyres & $6.5 \times 20$ inches 8 ply \\
\hline Inflation pressure (kPa) & 280 \\
\hline Rear tyres & $18.4 \times 3040$ ply \\
\hline Inflation pressure (kPa) & 160 \\
\hline
\end{tabular}


Table.2 Specification of test tractor II

\begin{tabular}{|l|l|}
\hline Specifications & Value \\
\hline Type/Model & Mahindra /575 DI \\
\hline Effective output (hp) & 45 \\
\hline Type of Engine & 4 Cylinder \\
\hline Type of steering system & Power Steering \\
\hline Type of injector pump & In line fuel injection pump \\
\hline Fuel tank capacity (L) & 53 \\
\hline Lifting capacity (kgf) & 1600 \\
\hline Rated engine speed (rpm) & 2300 \\
\hline Type of cooling system & Water cooled \\
\hline Front tyres & $6 \times 16$ inches \\
\hline Rear tyres & $13.6 \times 28$ inches \\
\hline
\end{tabular}

Table. 3 Draft requirement of primary and secondary tillage implements used in the study

\begin{tabular}{|l|l|l|l|}
\hline S.No & Implement Type & Mean & Std Dev. \\
\hline 1. & Moldboard Plough & $619.2 \pm 2 \%$ & 52.5 \\
\hline 2. & Disc plough & $690.2 \pm 2 \%$ & 30.7 \\
\hline 3. & Disc harrow & $147.2 \pm 2 \%$ & 10.5 \\
\hline 4. & Cultivator & $244.2 \pm 2 \%$ & 28.3 \\
\hline
\end{tabular}

Fig.1 Draft measurement tillage implement using pull type load cell in test plot

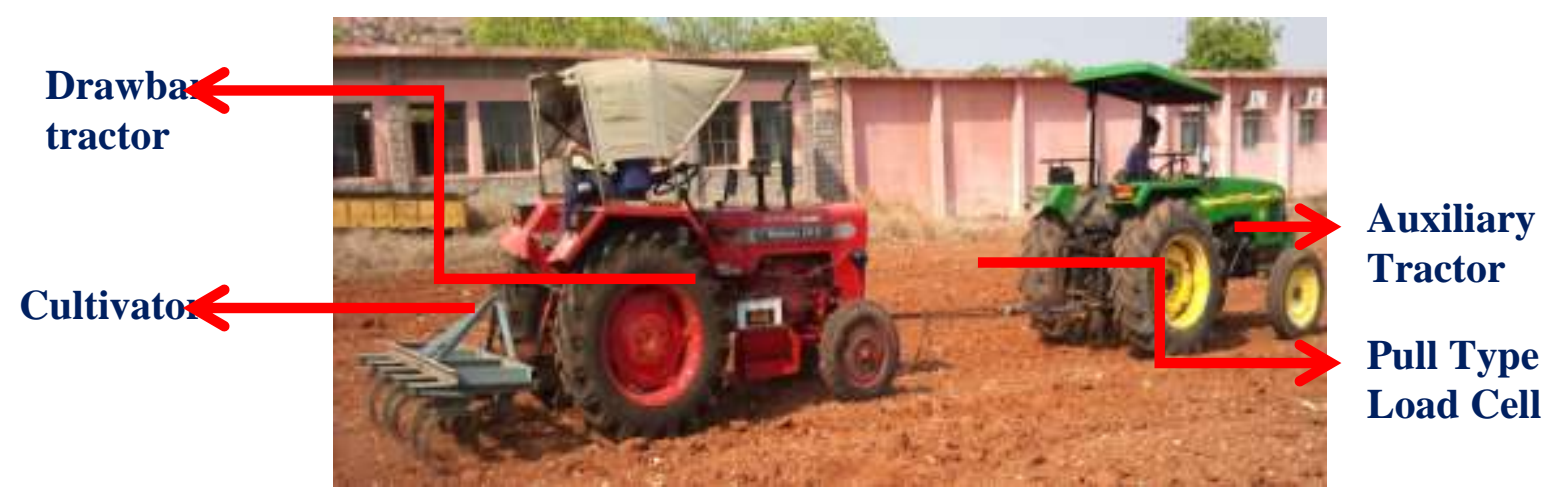

In conclusions draft requirement of tillage implement is necessary for proper tractor implement matching, and estimation of fuel consumption at different working condition. In India were mechanization level is still 51 $\%$, the draft requirement can serve as boon for increasing the input use efficiency of primary and secondary tillage implements. So draft measurement is required for suitable combination of tractor and implement to get desired results at low initial investment at minimum time without wastage of power and 
fuel consumption of tractor. Therefore the draft requirement data of primary and secondary tillage implements were determined using pull type load cell. The soil effecting parameters draft was also determined. The draft of $\mathrm{Mb}$ plough was found to be maximums at $619 \mathrm{kgf}$ at same moisture content and bulk density compared to selected implements for study. The large difference in draft requirement of different tillage implements shows substantial energy saving by selecting energy efficient tillage system.

\section{Suggestions for future work}

Keeping in view the importance of draft requirements for tillage implements, the following points are suggested for development of dynamometer and prediction of draft.

To develop a three point hitch dynamometer to predict draft, vertical force and inertia of the tillage implements.

To measure the draft of tillage implements at different soil conditions.

To determine the effect of draft on fuel consumption.

\section{Acknowledgement}

The authors express their appreciation to staff and management of southern region farm machinery training and testing institute Garladinne, Anantapur (AP) for permitting to conduct laboratory and field experiments in their institute.

\section{References}

Al-Suhaibani, A. A., and Y. N. Al-Janobi. 1997. Draft requirements of tillage implements operating on sandy loam soil. Journal of Agricultural Engineering Researches, 66(3): 177-
182.

Al-Suhaibani, A. A., Y. N. Al-Janobi, and AlMajhadi. 2010.Development and Evaluation of Tractors and Tillage Implements Instrumentation System. American Journal of Engineering and Applied Sciences, 3(2): 363-371.

ASABE Standards, 41 ${ }^{\text {st }}$ Ed. 1994. D497. Agricultural machinery management data. St. Joseph, Mich.: ASAE.

Bowers, J.R. and G. Crowell, 1985. Southeastern tillage energy data and recommended reporting.Transactions of the ASAE, 28: 731-737.

Finner, M. F., and R. J. Straub. 1985. Farm Machinery Fundamentals. Madison, WI: American Publishing. Co.

Gill, W. R., and G. E. V. Berg. 1967. Soil Dynamics in Tillage and Traction. In USDA Agricultural, Handbook No. 316, pp.171-181. USDA, Washington, D.C.

Gill, W. R., and G. E. V. Berg. 1968. Soil Dynamics in Tillage and Traction, In Agricultural Research Service, 211297. Washington, D. C.: USDA.

Grisso, R.D., M. Yasin and M.F. Kocher, 1996. Tillage implement forces operating in silty clay loam. ASAE Paper No. 94-1532. St. Joseph, Mich. ASAE.

Harrigan, T. M., and C. A. Rotz. 1994. Draft of major tillage and seeding equipment. ASAE Paper, No. 941533.

Larson, D.L. and H.E. Clyma, 1995. Electroosmosis effectiveness in reducing tillage draft force and energy forces. Transactions of ASAE, 38: 12811288.

Mamman, E., and K. C. Oni. 2005. Draught performance of a range of model chisel furrowers. CIGR Journal, 7(3): $1-14$.

Naderloo, L., R. Alimadani, A. Akram, P. Javadikia, and H. Z. Khanghah. 2009. 
Tillage depth and forward speed effects on draft of three Primary tillage implements in clay loam Soil. Journal of Food, Agriculture and Environment, 76(3): 382-385.

Okoko, P. 2017. Draft and power requirements of some tillage implements for selected soils in Uyo local Government Area of Akwa-Ibom State. Ph.D. diss., Department of Agriculturaland Environmental Engineering, University of Ibadan, Ibadan.

Olatunji, O. M., W. I. Burubai, and R. M. Davies. 2009. Effect of weight and draught on the performance of disc plough on sandy loam soil. Research Journal of Applied Sciences, Engineering and Technology, 1(1): 22-26.

Srivastava, A. K., E. G. Carroll, P. R. Roger, and R. B. Dennis. 2006. (rev.) Soil Tillage. In Engineering Principles of
Agricultural Machines, $2^{\text {nd }}$ ed, ch. 8 , 169-230. St. Joseph, Michigan: ASABE.

Taniguchi, T., J. T. Makanga, K. Ohtomo, and T. Kishimoto. 1999. Draft and soil manipulation by a mould board Plow under different formed speed and body attachments. Transactions of the ASAE, 42(6): 1517.

Upadhyaya, S. K., K. Andrade-Sanchez, K. Sakai, W. J. Chancellor, and R. J. Godwin. 2009. Energy requirement for soil break-up. In Advances in Soil Dynamics, ch. 3, parts I and II, 273359. St. Joseph, Michigan, U.S.A.: American Society of Agricultural and Biological Engineers

Zwilling, E. L., and J. W. Hummel. 1988. Draft and energy requirements for Midwest tillage operations. ASAE Paper, No.88-1115. St Joseph, MI. ASAE.

\section{How to cite this article:}

Bikram Jyoti, K.V.S Ram Reddy, Chetankumar P. Sawant, A.P. Pandirwar, R.R. Potdar and Randhe, R.D. 2019. Predicting Draft Requirement of Tillage Implements Using Pull Type Load Cell in Southern Region of Andhra Pradesh, India. Int.J.Curr.Microbiol.App.Sci. 8(01): 606612. doi: https://doi.org/10.20546/ijcmas.2019.801.068 